\title{
Kemampuan Representasi Matematis Siswa Kelas XI melalui Penerapan Model Problem Based Learning
}

\author{
Susilawati ${ }^{1}$, Tjang Daniel Chandra ${ }^{1}$, Abadyo $^{1}$ \\ ${ }^{1}$ Pendidikan Matematika-Universitas Negeri Malang
}

\begin{tabular}{|c|c|}
\hline INFO ARTIKEL & ABSTRAK \\
\hline Riwayat Artikel: & $\begin{array}{l}\text { Abstract: The purpose of this study is to describe the application of PBL to improve the } \\
\text { representation ability of class XI students. This classroom action research was carried out }\end{array}$ \\
\hline Diterima: 25-02-2019 & in 2 cycles, which were conducted from October to November 2018. The results of this \\
\hline Disetujui: 20-09-2019 & study were the application of PBL models to mathematics learning that had improved \\
\hline Kata kunci: & $\begin{array}{l}\text { students mathematical representation skills, which were supported by increased } \\
\text { achievement of teacher and student activities from cycles I to cycle. }\end{array}$ \\
\hline $\begin{array}{l}\text { problem based learning; } \\
\text { mathematical representation; } \\
\text { high school student; } \\
\text { problem based learning; } \\
\text { representasi matematis; } \\
\text { siswa SMA }\end{array}$ & $\begin{array}{l}\text { Abstrak: Tujuan penelitian ini adalah mendeskripsikan penerapan PBL untuk } \\
\text { meningkatkan kemampuan representasi matematis siswa kelas XI. Penelitian tindakan } \\
\text { kelas ini dilakukan dalam dua siklus yang dilaksanakan pada bulan Oktober-November } \\
\text { 2018. Hasil dari penelitian ini adalah penerapan model PBL pada pembelajaran } \\
\text { matematika telah meningkatkan kemampuan representasi matematis siswa yang } \\
\text { ditunjukkan dengan adanya peningkatan capaian kemampuan representasi matematis } \\
\text { siswa secara klasikal dan aktivitas guru serta siswa mengalami peningkatan dari siklus I } \\
\text { ke siklus II. }\end{array}$ \\
\hline \multicolumn{2}{|l|}{ Alamat Korespondensi: } \\
\hline $\begin{array}{l}\text { Susilawati } \\
\text { Pendidikan Matematika } \\
\text { Universitas Negeri Malang } \\
\text { Jalan Semarang } 5 \text { Malang } \\
\text { E-mail: susipmk@gmail.com }\end{array}$ & \\
\hline
\end{tabular}

Kemampuan Representasi penting bagi siswa dalam belajar matematika, karena dengan representasi siswa dapat mengemukakan hal-hal abstrak dari matematika ke dalam bahasa lisan, simbol tertulis, dan gambar (NCTM, 2000; Sabirin, 2014). Representasi membantu siswa dalam meningkatkan pemahaman siswa terhadap konsep matematika, memecahkan masalah matematika, dan mengomunikasikan gagasan matematisnya ( Hwang, Chen, \& Yang, 2007; Debrenti, 2015; Arnidha, 2016; Faruq, Yuwono, \& Chandra, 2016; Thompson \& Chappell, 2007; Rahmad dkk, 2016; Kartini, 2009). Di sekolah menengah atas, representasi berfungsi untuk memperjelas penyelesaian suatu masalah, atau mengembangkan ide-ide siswa tentang matematika yang diawali dengan proses pengumpulan fakta (data), penyusunan tabel atau grafik, sampai pada pengembangan representasi simbolik (Dahlan \& Juandi, 2011). Representasi adalah notasi simbolik atau grafis untuk mengungkapkan suatu gagasan konsep matematis yang prosesnya bersifat relevan dan karakteristiknya diekspresikan (José Madrid, Maz-Machado, \& León-Mantero, 2015)

Siswa yang aktif akan membangun ide-ide matematis mereka secara mandiri, sedangkan siswa yang pasif hanya memperoleh pengetahuan dari guru tanpa diberi kesempatan untuk membangun ide-ide matematisnya. (Hwang et al., 2007) menyatakan bahwa representasi siswa akan berkembang jika mereka terlibat secara langsung dalam pemecahan masalah dan tidak hanya dengan membiasakan siswa mendengarkan serta menyimak penjelasan oleh guru. Permasalahan pembelajaran dalam matematika adalah siswa cenderung mengikuti representasi yang sudah dicontohkan oleh guru dan siswa jarang diberi kesempatan untuk menghadirkan representasinya sendiri, sehingga kemampuan representasi siswa rendah (Hutagaol, 2013).

Berdasarkan hasil pengamatan peneliti diketahui bahwa kemampuan representasi siswa masih rendah. Dalam menyelesaikan soal cerita siswa cenderung mencontoh guru, siswa merasa kesulitan dalam menyusun model matematika. Siswa hanya menghafal langkah-langkah pengerjaan yang dicontohkan oleh guru, tanpa memahami konsep dan langkah yang mereka kerjakan. Sebagai contoh, berikut contoh hasil pekerjaan siswa seperti pada gambar 1.

Salah satu siswa yang tidak bisa menyelesaikan masalah matematika disebabkan karena salah dalam memodelkan soal cerita ke dalam bentuk matematika seperti pada gambar 1. Soal tersebut adalah "Ani, Ana dan Tika pergi bersama ke toko buku "Gramedia" untuk membeli buku tulis dan bolpoin. Ani membayar Rp 5200,00 untuk 2 buku tulis dan 3 bolpoin, sedangkan Tika membayar Rp 6.200,00 untuk 4 buku tulis dan 2 bolpoin. Berapakah uang yang dikeluarkan Ana untuk membayar 1 buku tulis dan 1 bolpoin?". 


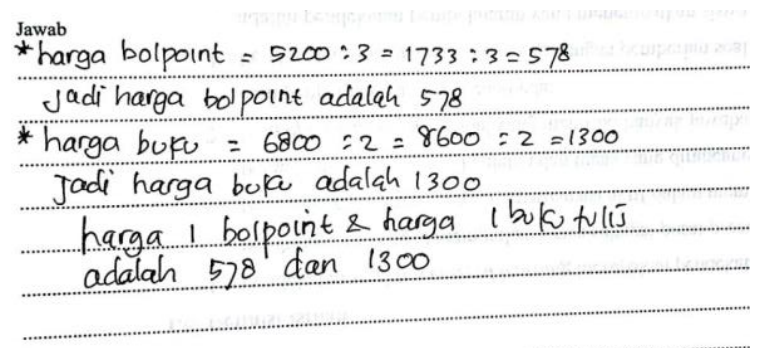

\section{Gambar 1. Contoh Jawaban Siswa}

Berdasarkan gambar 1 terlihat bahwa siswa belum dapat menyusun model matematika dengan benar, siswa juga tidak menuliskan simpulan akhir dengan benar. Dari jawaban siswa terlihat bahwa kemampuan representasi siswa rendah. Sehingga diperlukan perbaikan pembelajaran untuk mengatasi masalah tersebut di atas. Model PBL dipilih oleh peneliti untuk meningkatkan kemampuan representasi siswa. PBL merupakan suatu model pembelajaran diawali dengan masalah nyata yang dihadapi oleh siswa dalam kehidupan mereka (Priyono, Hermanto, Studi, Matematika, \& Siliwangi, 2015). Dalam model PBL siswa berperan aktif sehingga siswa dapat mengungkapkan representasi pemecahan masalah sesuai dengan ide yang mereka miliki dan guru bertindak sebagai fasilitator (Chakrabarty \& Mohamed, 2013).

Penelitian sebelumnya mengatakan bahwa implementasi model PBL dalam pembelajaran matematika, dapat meningkatkan hasil belajar, keaktifan siswa dan representasi matematis siswa. Seperti yang disampaikan oleh (Farhan \& Retnawati, 2014; Fitri, Munzir, \& Duskri, 2017; Kusumaningsih \& Marta, 2016) bahwa untuk meningkatkan hasil belajar siswa dan kemampuan representasi matematis siswa, model PBL lebih efektif dibandingkan dengan model konvensional. Para guru belum terbiasa menggunakan PBLuntuk meningkatkan pemahaman matematis dan kemampuan representasi matematika siswa (Minarni, Napitupulu, \& Husein, 2016).

Peneliti memilih materi program linear dua variabel karena materi ini adalah materi pada kelas XI semester ganjil pada kurikulum K13. Siswa dapat menerapkan materi yang diperoleh untuk menyelesaikan masalah mereka yang menuntut kemampuan representasi dalam menggambar grafik, tabel dan menyusun model matematika dari soal cerita. Di SMA Negeri 5 Pamekasan masih banyak siswa yang memiliki kemampuan representasi rendah, mereka cenderung mencontoh representasi guru ketika menyelesaikan masalah. Salah satu penyebab kenyataan ini adalah peran guru dalam pembelajaran sangat dominan, sehingga siswa kurang memiliki kesempatan untuk merepresentasikan ide-ide mereka.

\section{METODE}

Penelitian ini bersifat deskriptif kualitatif dan jenis Penelitian ini adalah Penelitian Tindakan Kelas. Penelitian Tindakan Kelas ini dilakukan dalam dua siklus. Peneliti sebagai instrumen utama yang merancang, melaksanakan, mengumpulkan dan menganalisa data, menarik kesimpulan serta membuat laporan.. Prosedur PTK ini dirancang dengan bentuk siklus, terdapat empat tahapan dalam penelitian ini, yaitu (1) merencanakan, (2) melaksanakan, (3) mengobservasi, dan (4) merefleksi. Penelitian ini dilakukan di sekolah di Pamekasan pada semester ganjil tahun pelajaran 2018/2019. Data dan sumber data yang dikumpulkan dalam penelitian ini seperti pada tabel 1 .

\section{Tabel 1. Data dan Sumber Data}

\begin{tabular}{cll}
\hline No & \multicolumn{1}{c}{ Data } & \multicolumn{1}{c}{ Sumber Data } \\
\hline 1 & Hasil validasi perangkat pembelajaran dan instrumen penelitian & Lembar validasi \\
2 & Hasil observasi aktivitas guru dan siswa & Lembar observasi aktivitas guru dan siswa \\
3 & Hasil Tes pada tiap akhir siklus & Lembar jawaban siswa \\
4 & Kejadian yang tidak terekam di lembar observasi & Lembar catatan lapangan \\
\hline
\end{tabular}

Analis data pada penelitian ini dilakukan dengan mereduksi data, menyajikan data, dan menarik kesimpulan. Tindakan PBL pada penelitian ini berhasil jika (1) hasil observasi dari aktivitas guru dan siswa pada saat pembelajaran minimal pada kategori baik dan (2) secara klasikal $75 \%$ dari seluruh siswa memperoleh hasil capaian kemampuan representasi matematis minimal pada level 3, dengan kriteria seperti pada tabel 2. 
Tabel 2. Indikator Level Pencapaian Representasi

\begin{tabular}{|c|c|}
\hline Kategori & Representasi Matematis \\
\hline Level 5 & $\begin{array}{l}\text { Menyusun model matematika dari masalah program linear dengan benar dan lengkap } \\
\text { Menggambar grafik daerah selesaian dari masalah program linear dengan benar dan lengkap } \\
\text { Menuliskan simpulan dari selesaian yang diperoleh dengan menggunakan kata-kata dengan benar dan lengkaa }\end{array}$ \\
\hline Level 4 & $\begin{array}{l}\text { Menyusun model matematika dari masalah program linear dengan benar dan lengkap } \\
\text { Menggambar grafik daerah selesaian dari masalah program linear dengan benar dan tidak lengkap } \\
\text { Menuliskan simpulan dari selesaian yang diperoleh dengan menggunakan kata-kata dengan tidak benar }\end{array}$ \\
\hline Level 3 & $\begin{array}{l}\text { Menyusun model matematika dari masalah program dengan benar dan lengkap } \\
\text { Menggambar grafik daerah selesaian dari masalah program linear dengan tidak benar dan tidak lengkap } \\
\text { Menuliskan simpulan dari selesaian yang diperoleh dengan menggunakan kata-kata dengan tidak benar }\end{array}$ \\
\hline Level 2 & $\begin{array}{l}\text { Pembuatan model matematika dari masalah program dengan tidak benar } \\
\text { Pembuatan representasi grafik grafik daerah selesaian dari masalah program linear dengan tidak benar } \\
\text { Tidak menuliskan simpulan dari selesaian yang diperoleh dengan menggunakan kata-kata }\end{array}$ \\
\hline Level 1 & Hanya pada proses mencoba menyelesaikan namun belum selesai \\
\hline
\end{tabular}

\section{HASIL \\ Siklus I \\ Perencanaan}

Pada perencanaan peneliti mempersiapkan RPP dan LKS yang bercirikan PBL, lembar observasi aktivitas guru dan siswa, kisi-kisi soal tes akhir siklus, lembar soal tes akhir siklus, serta alternatif jawaban soal tes akhir siklus yang telah divalidasi.

\section{Tindakan}

Pada siklus ini dilakukan tindakan pembelajaran dalam empat pertemuan, tanggal 30 Oktober-7 November 2018. Pertemuan pertama dan kedua membahas tentang model matematika. Pertemuan ketiga membahas tentang grafik daerah selesaian suatu masalah program linear dua variabel. Pada pertemuan keempat diadakan tes akhir siklus I. Tes akhir siklus dilaksanakan hari Rabu, tanggal 7 November 2018 dari pukul pada pukul 07.00-08.15. Soal yang harus dikerjakan siswa sebanyak satu soal. Siswa yang mengikuti tes ini sebanyak 26 orang. Hasil tes diperoleh bahwa capaian level kemampuan representasi belum maksimal, dua siswa mencapai level 5, lima siswa mencapai level 4, sembilan siswa mencapai level 3, delapan siswa mencapai level 2, dan dua siswa mencapai level 1 dari 26 siswa. Jadi, persentase capaian kemampuan representasi matematis mencapai minimal level 3 sebesar 61,5\%. Pada saat fase penyelidikan mandiri dan kelompok, beberapa siswa tampak kebingungan untuk menentukan informasi yang ada pada kasus. Beberapa kelompok menuliskan ulang soal cerita pada lembar kerja siswa seperti pada gambar 2. Guru mengatasi hal ini secara klasikal dengan menjelaskan bahwa cukup menuliskan apa yang diketahui dan apa yang ditanyakan dari masalah.

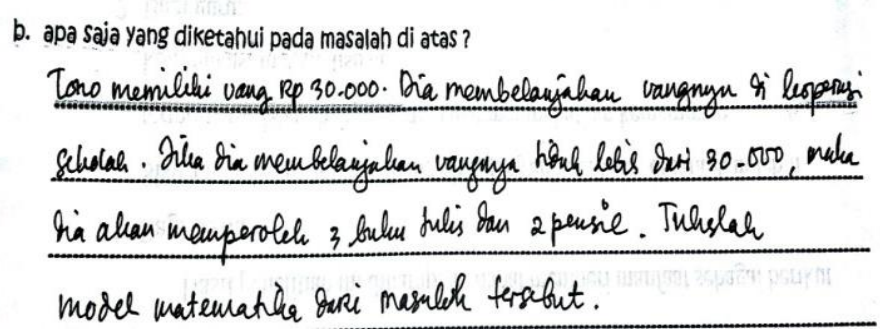

Gambar 2. Jawaban Salah Satu Kelompok

\section{Observasi}

Observasi dilakukan oleh dua orang teman sejawat peneliti selama pembelajaran di kelas. Dari hasil pengamatan terlihat bahwa respons siswa terhadap pembelajaran dengan baik. Pertemuan pertama diskusi tidak sesuai dengan harapan peneliti, pertemuan kedua dan ketiga siswa cukup bersemangat dan aktif dalam berdiskusi. Siswa berkemampuan tinggi terlihat dominan dalam diskusi dan siswa belum terbiasa dengan PBL. Pertemuan kedua dan ketiga siswa sudah terbiasa dengan PBL. Siswa sudah berani untuk mengungkapkan pendapatnya saat diskusi kelompok atau diskusi kelas. Siswa menyiapkan materai untuk pertemuan yang akan datang dengan mencari informasi dari berbagai sumber. Observer juga mengamati bahwa ada beberapa siswa yang 
belum aktif dalam pembelajaran dan guru tidak memperhatikannya. Kedua observer juga memberi saran kepada peneliti agar memperhatikan alokasi waktu pada RPP sehingga pelaksanaan pembelajaran sesuai dengan telah direncanakan.

Hasil observasi aktivitas guru yang selama tiga pertemuan dapat dilihat pada tabel 3. Persentase observasi aktivitas guru pertemuan pertama adalah 66,05 \% dengan kriteria baik, pertemuan kedua adalah 73,33\% dengan kriteria baik dan pertemuan ketiga adalah 78,22 \% dengan kriteria baik. Rata-rata persentase hasil observasi aktivitas guru adalah 75,53\% dengan kriteria baik. Artinya, guru berperan baik dalam kegiatan pembelajaran. Hasil observasi kegiatan siswa selama tiga pertemuan sebagaimana ditunjukkan pada tabel 4.

Tabel 3. Hasil Observasi Aktivitas Guru

\begin{tabular}{clcccc}
\hline \multirow{2}{*}{ No } & \multirow{2}{*}{ Kegiatan Pembelajaran } & \multicolumn{2}{c}{ Hasil Observasi } & \multirow{2}{*}{ Rata-rata Hasil Observasi } & \multirow{2}{*}{ Kesimpulan } \\
\cline { 3 - 4 } & & O1 & O2 & & \\
\hline 1 & Pertemuan 1 & $64,28 \%$ & $67,86 \%$ & $66,05 \%$ & Baik \\
2 & Pertemuan 2 & $73,33 \%$ & $73,33 \%$ & $73,33 \%$ & Baik \\
3 & Pertemuan 3 & $78,33 \%$ & $78,12 \%$ & $78,22 \%$ & Baik \\
\hline & Rata-rata & & & $72,53 \%$ & Baik \\
\hline
\end{tabular}

Tabel 4. Hasil Observasi Aktivitas Siswa

\begin{tabular}{clllll}
\hline \multirow{2}{*}{ No } & \multirow{2}{*}{ Kegiatan Pembelajaran } & \multicolumn{2}{c}{ Hasil Observasi } & \multirow{2}{*}{ Rata-rata Hasil Observasi } & \multirow{2}{*}{ Kesimpulan } \\
\cline { 3 - 4 } & & \multicolumn{1}{c}{ O1 } & \multicolumn{1}{c}{ O2 } & & \\
\hline 1 & Pertemuan 1 & $62,50 \%$ & $62,50 \%$ & $62,50 \%$ & Baik \\
2 & Pertemuan 2 & $65 \%$ & $66,67 \%$ & $65,83 \%$ & Baik \\
3 & Pertemuan 3 & $71,83 \%$ & $68,3 \%$ & $70,06 \%$ & Baik \\
\hline & Rata-rata & & & $66,13 \%$ & Baik \\
\hline
\end{tabular}

Persentase observasi aktivitas siswa pertemuan pertama adalah 62,50\% dengan kriteria baik. pertemuan kedua adalah $65,83 \%$ dengan kriteria baik dan pertemuan ketiga adalah 70,06\% dengan kriteria baik. Rata-rata persentase hasil observasi aktivitas siswa adalah 66,13\% dengan kriteria baik. Artinya, siswa mengikuti kegiatan pembelajaran dengan baik. Dari tabel 3 dan 4 diperoleh bahwa aktivitas guru dan siswa baik dan mengalami peningkatan.

\section{Refleksi}

Berdasarkan pelaksanaan tindakan, keterlaksanaan pembelajaran pada tiga pertemuan dalam kategori baik. Selain melihat keterlaksanaan pembelajaran, hasil tes akhir siklus juga menjadi pertimbangan akan keberhasilan tindakan. Hasil tes akhir menunjukkan capaian kemampuan representasi matematis siswa yang berada pada minimal level 3 sebanyak 16 siswa dari 26 siswa yang mengikuti tes atau sebesar 61,5\%. Secara klasikal hasil tes akhir belum memenuhi kriteria dan penelitian dilanjutkan pada siklus II. Peneliti menganalisa kelebihan dan kelemahan proses pembelajaran pada siklus I sebelum melanjutkan ke siklus II. Kelebihan pada siklus I akan tetap diperhatikan, sedangkan kelemahan pada siklus I diperbaiki.

Peneliti mengalami kesulitan menerapkan langkah-langkah sesuai dengan RPP yang telah rancang, namun peneliti tetap berusaha mengacu kepada RPP tersebut. Dalam siklus I peneliti menyampaikan tujuan pembelajaran dan ilustrasi permasalahan program linear untuk memotivasi siswa. Memberikan ilustrasi tentang masalah program linear dan menyampaikan tujuan pembelajaran di awal pembelajaran akan tetap dilakukan pada siklus II.

Pada pertemuan pertama pembelajaran berkelompok tidak berjalan dengan baik. Guru mengatasi dengan memberikan motivasi dan mengingatkan siswa bahwa dengan belajar secara berkelompok akan lebih memudahkan siswa untuk memahami dan menyelesaikan masalah. Setelah guru memotivasi dan mengingatkan siswa, siswa dapat bekerja sama dengan teman kelompoknya. Pada pertemuan berikutnya, keaktifan siswa berdiskusi dan bekerja sama dalam kelompok lebih meningkat sehingga kelompok yang terbentuk pada siklus I akan digunakan pada siklus II. Kelemahan siklus I akan diperbaiki pada siklus berikutnya seperti pada tabel 5 . 
Tabel 5. Kelemahan dan Rencana Perbaikan

\begin{tabular}{cll}
\hline No & \multicolumn{1}{c}{ Kelemahan } & \multicolumn{1}{c}{ Rencana Perbaikan } \\
\hline 1 & $\begin{array}{l}\text { Lebih dari 50\% siswa kurang memahami tentang sistem } \\
\text { persamaan linear dua variabel dan pertidaksamaan linear satu } \\
\text { variabel serta menggambar grafik }\end{array}$ & $\begin{array}{l}\text { Sebelum siklus II dilaksanakan, guru membahas kembali materi } \\
\text { prasyarat. Pelaksanaannya di laksanakan di luar pembelajaran di } \\
\text { kelas. }\end{array}$ \\
2 & $\begin{array}{l}\text { Setiap kelompok hanya mendapatkan satu lembar kerja siswa } \\
\text { Waktu yang digunakan untuk pembelajaran melebihi dari } \\
\text { alokasi waktu yang direncanakan }\end{array}$ & $\begin{array}{l}\text { Guru memberikan 2-3 lembar kerja dalam setiap kelompok. } \\
\text { memperhatikan waktu agar sesuai dengan yang direncanakan } \\
\text { dalam RPP }\end{array}$ \\
$\begin{array}{l}\text { Perhatian guru terhadap siswa saat menyelesaikan masalah } \\
\text { kurang menyeluruh, karena hanya memperhatikan siswa yang } \\
\text { bertanya saja, sedangkan yang tidak bertanya kurang } \\
\text { mendapatkan perhatian }\end{array}$ & $\begin{array}{l}\text { Guru lebih memperhatikan semua siswa secara menyeluruh, dan } \\
\text { lebih mengoptimalkan kerja kelompok sehingga siswa yang } \\
\text { belum bisa memahami dan menyelesaikan masalah dapat } \\
\text { dibantu oleh temannya. }\end{array}$ \\
\hline
\end{tabular}

\section{Siklus II \\ Perencanaan}

Pada perencanaan peneliti mempersiapkan RPP dan LKS yang bercirikan PBL, lembar observasi aktivitas guru dan siswa, kisi-kisi soal tes akhir siklus, lembar soal tes akhir siklus, serta alternatif jawaban soal tes akhir siklus yang telah. Sebelum siklus II dilaksanakan, guru memantapkan materi prasyarat yang telah diberikan pada siklus I. Siklus II dilaksanakan setelah siswa siap mengikuti pembelajaran.

\section{Tindakan}

Pada siklus ini dilakukan tindakan berupa pembelajaran dalam tiga pertemuan, tanggal 13 November-20 November 2018. Pertemuan pertama dan kedua membahas tentang bagaimana menentukan nilai optimum suatu masalah program linear. Pada pertemuan ketiga diadakan tes akhir. Tes akhir siklus dilaksanakan hari Selasa tanggal 20 November 2018 dari pukul 12.30 13.45. Soal yang harus dikerjakan siswa sebanyak satu soal. Siswa yang mengikuti tes ini sebanyak 26 orang. Hasil tes akhir siklus menunjukkan bahwa capaian level kemampuan representasi matematis siswa sudah memenuhi kriteria keberhasilan, karena 23 siswa dari 26 siswa yang mengikuti tes mencapai minimal level 3 dan tiga siswa masih mencapai level 2. Persentase capaian kemampuan representasi matematis sebesar $88,46 \%$.

\section{Observasi}

Hasil pengamatan oleh observer menyatakan bahwa siswa dapat merespons pembelajaran dengan baik. Mereka cukup antusias dalam mengikuti proses pembelajaran dan aktif berdiskusi pada pertemuan pertama dan kedua. Siswa telah berani untuk mengungkapkan pendapatnya pada saat diskusi kelompok atau diskusi kelas. Observer juga mengamati bahwa beberapa siswa yang belum aktif dalam pembelajaran siklus I, pada siklus ini sudah ada peningkatan setelah ada perhatian dari guru.

Pembelajaran sesuai dengan alokasi waktu yang direncanakan karena siswa sudah mulai terbiasa belajar mandiri, mereka benar-benar menggali informasi dari berbagai sumber tentang materi pada pembelajaran yang akan datang. Berdasarkan pelaksanaan tindakan siklus II, kemampuan dalam menerapkan langkah-langkah pembelajaran sudah lebih meningkat dibandingkan pada siklus I. Selain melihat keterlaksanaan pembelajaran hasil tes akhir siklus juga menunjukkan peningkatan pada capaian kemampuan representasi matematis siswa. Hasil observasi aktivitas guru untuk dua pertemuan dapat dilihat pada tabel 6.

Persentase observasi aktivitas guru pertemuan pertama adalah 85,75\% dengan kriteria sangat baik, pertemuan kedua adalah $85,9 \%$ dengan kriteria sangat baik. Artinya guru berperan sangat baik dalam kegiatan pembelajaran dan aktivitas yang dilakukan oleh guru sesuai dengan RPP. Hasil observasi kegiatan siswa untuk dua pertemuan dapat dilihat pada tabel 7. Persentase observasi aktivitas siswa pertemuan pertama adalah 76,65 \% dengan kriteria baik, pertemuan kedua adalah 80,37\% dengan kriteria sangat baik. Aktivitas guru dan aktivitas siswa mengalami peningkatan.

Berdasarkan pelaksanaan tindakan, kemampuan dalam menerapkan langkah-langkah pembelajaran sudah lebih meningkat dibandingkan pada siklus I. Selain itu, hasil tes akhir siklus II juga menunjukkan peningkatan pada capaian kemampuan representasi matematis siswa. Kemampuan siswa untuk terlibat aktif dalam setiap diskusi meningkat, dan peran siswa berkemampuan tinggi sudah tidak dominan. Siswa juga sudah mampu belajar secara mandiri. Alokasi waktu pada setiap pertemuan sudah sesuai dengan rencana karena siswa sudah mulai terbiasa dengan model pembelajaran PBL. 
Tabel 6. Hasil Observasi Aktivitas Guru

\begin{tabular}{cccccc}
\hline \multirow{2}{*}{ No } & \multirow{2}{*}{ Kegiatan Pembelajaran } & \multicolumn{2}{c}{ Hasil Observasi } & \multirow{2}{*}{ Rata-rata Hasil Observasi } & \multirow{2}{*}{ Kesimpulan } \\
\cline { 3 - 4 } & Pertemuan I & $89,3 \%$ & $82,2 \%$ & $85,75 \%$ & Sangat baik \\
\hline 1 & Pertemuan II & $84,3 \%$ & $87,5 \%$ & $85,9 \%$ & Sangat baik \\
\hline & & & & $85,3 \%$ & Sangat baik \\
\hline
\end{tabular}

Tabel 7. Hasil Observasi Aktivitas Siswa

\begin{tabular}{cccccc}
\hline \multirow{2}{*}{ No } & \multirow{2}{*}{ Kegiatan Pembelajaran } & \multicolumn{2}{c}{ Hasil Observasi } & \multirow{2}{*}{ Rata-rata Hasil Observasi } & \multirow{2}{*}{ Kesimpulan } \\
\cline { 3 - 5 } & O1 & O2 & $76,65 \%$ & Baik \\
\hline 1 & Pertemuan I & $75 \%$ & $81,3 \%$ & $80,37 \%$ & Sangat baik \\
\hline & Pertemuan II & $78 \%$ & $82,11 \%$ & $78,51 \%$ & Baik \\
\hline
\end{tabular}

\section{PEMBAHASAN}

Tahapan penerapan model PBL pada pembelajaran untuk materi program linear adalah sebagai berikut.

\section{Fase Mengarahkan Siswa pada Masalah}

Siswa diarahkan untuk melakukan merumuskan masalah yang diberikan, dengan menuliskan apa yang diketahui dan ditanya. Masalah atau pertanyaan yang diajukan harus menarik dan jelas, mudah dipahami, memiliki ruang lingkup yang luas dan bermanfaat (Arends, 2012). Guru juga menyampaikan tujuan pembelajaran dan ilustrasi permasalahan program linear untuk memotivasi siswa belajar. (Hakim, 2012) menyatakan bahwa motivasi dapat membuat siswa memiliki semangat untuk belajar dan dapat memberikan arah dalam belajar. Siswa akan memperoleh hasil belajar yang lebih baik jika mempunyai tujuan yang berasal dari diri sendiri atau diberikan oleh orang lain (Hakim, 2012). Selanjutnya, guru memberikan penjelasan tentang langkahlangkah PBL agar siswa memahami kegiatan yang akan mereka lakukan. Hal ini sesuai dengan pendapat (Arends, 2012) bahwa seorang guru memiliki kewajiban untuk menyampaikan tujuan pembelajaran dengan jelas, motivasi dan hal-hal lain yang akan dilakukan oleh siswa.

\section{Fase Mengorganisasikan Siswa untuk Belajar}

Guru membagi siswa menjadi lima kelompok. (Chakrabarty \& Mohamed, 2013) menyatakan bahwa PBL adalah student centered learning di mana pembelajaran ini bertujuan pada penekanan proses pembelajaran sehingga siswa tersebut mendapatkan solusi yang didukung oleh guru sebagai fasilitator. (Rashid, 2011) menyatakan bahwa pengetahuan siswa berkembang tidak sepenuhnya bergantung pada guru, namun mereka belajar secara mandiri atau kelompok untuk mendapatkan pengetahuan. Kelompok belajar pada setiap pertemuan anggotanya sama, agar antar siswa bisa lebih saling memahami dan tidak sungkan dalam mengemukakan ide-idenya. Pembelajaran berkelompok pada PBL berpengaruh positif terhadap cara belajar siswa dalam mendapatkan ide (Chakrabarty \& Mohamed, 2013).

\section{Fase Membantu Penyelidikan Mandiri dan Kelompok}

Guru berkeliling ke setiap kelompok untuk memastikan bahwa kegiatan yang dilakukan oleh siswa telah berjalan sesuai dengan instruksi guru dan guru membantu siswa atau kelompok yang mengalami kesulitan. PBL merupakan perbelajaran yang berpusat pada siswa untuk mendapatkan solusi dari masalah dan guru sebagai fasilitator (Chakrabarty \& Mohamed, 2013).

\section{Fase Mengembangkan dan Menyajikan Hasil Karya}

Guru mempersilahkan siswa untuk menampilkan hasil diskusinya. Siswa mengembangkan pengetahuan melalui penelitian, mengintegrasikan teori-teori untuk dipraktekkan dan menerapkan pengetahuan melalui keterampilan sehingga dapat menyelesaikan masalah (Savery, 2006). Menyajikan hasil yang pada saat diskusi kelompok di depan kelas. Penulisan hasil karya dapat dituliskan di tempat yang telah disediakan di LKS. (Arends, 2012) menyatakan bahwa siswa yang menghasilkan hasil karya wajib didemontrasikan sebagai wujud bahwa siswa telah mendapatkan solusi dari masalah. 
Fase Menganalisis dan Mengevaluasi Proses Pemecahan Masalah

Guru membantu siswa melakukan analisis dan evaluasi melalui refleksi hasil diskusi kelompok. Guru mengarahkan siswa untuk melakukan pemeriksaan kembali terhadap proses dan hasil yang diperoleh. Guru juga membimbing siswa dengan melakukan tanya jawab untuk mengarahkan siswa membuat kesimpulan. (Macmath, Sheryl, Wallace, \& Xiaohong, 2009) menyatakan bahwa guru juga bertugas untuk mendorong mereka dalam mempertimbangkan suatu cara atau strategi untuk menemukan solusinya.

Penerapan model PBL pada materi program linear telah meningkatkan kemampuan representasi matematis yang dimiliki oleh siswa. Peningkatan tersebut menunjukkan bahwa penerapan PBL telah menjadikan proses pembelajaran yang lebih bermakna. PBL memiliki pengaruh positif terhadap cara belajar siswa dalam menghasilkan ide, serta siswa mendapatkan keberhasilan dalam mengembangkan keterampilan seperti pemecahan masalah, berpikir kritis, ketrampilan berkomunikasi dan membantu siswa untuk melihat koneksi antara matematika dan penerapannya pada dunia nyata (Chakrabarty \& Mohamed, 2013). Peningkatan tersebut dapat dilihat dari peningkatan capaian kemamapuan representasi matematis siswa pada tes akhir siklus. Pada tes akhir siklus I terdapat sebanyak 16 dari 26 siswa atau sebesar 61,5\% yang memperoleh capaian kemampuan representasi matematis minimal level 3. Pada siklus II meningkat sebanyak 23 dari 26 siswa atau 88,46\% yang memperoleh capaian kemampuan representasi matematis minimal level 3.

Selain itu, peningkatan hasil belajar pada siklus II juga dipengaruhi oleh aktivitas siswa dan guru pada proses pembelajaran dengan PBL. Hasil observasi aktivitas guru pada siklus pertama sebesar 75,53\% dengan kategori baik, siklus kedua sebesar 85,83 \% dengan kategori sangat baik. Hal ini menunjukkan bahwa aktivitas guru meningkat. Selain itu, aktivitas siswa juga mengalami peningkatan. Pembelajaran telah mampu membuat siswa lebih aktif karena pembelajaran lebih berpusat pada siswa. Pembelajaran juga membuat siswa lebih mandiri dalam mengerjakan tes dan tugas, percaya diri terhadap jawaban yang telah diperoleh, lebih berani mengungkapkan pendapat, lebih aktif saat pembelajaran melalui pertanyaan-pertanyaan, serta dapat memahami dan menyelesaikan masalah dengan baik dan benar. Hasil rekap peningkatan hasil pembelajaran yang dilakukan peneliti seperti pada tabel 8 .

Tabel 8. Rekap Peningkatan Hasil Pembelajaran

\begin{tabular}{|c|c|c|c|c|}
\hline \multirow{2}{*}{ No } & \multirow{2}{*}{ Kriteria } & \multicolumn{2}{|c|}{ Siklus } & \multirow{2}{*}{ Keterangan } \\
\hline & & I & II & \\
\hline 1 & Hasil Observasi Aktivitas Siswa & $66,13 \%$ & $78,51 \%$ & Meningkat \\
\hline 2 & Hasil Observasi Aktivitas Guru & $72,53 \%$ & $85,83 \%$ & Meningkat \\
\hline 3 & Ketuntasan Pembelajaran di Kelas secara Klasikal & $61,5 \%$ & $88,46 \%$ & Meningkat \\
\hline
\end{tabular}

Aktivitas guru dan siswa meningkat dari siklus I ke siklus II. Hasil tes akhir siklus juga meningkat sehingga ketuntasan pembelajaran di kelas secara klasikal meningkat. Dapat diambil simpulan bahwa penerapan PBL untuk meningkatkan kemampuan representasi matematis pada penelitian ini disimpulkan telah berhasil.

\section{SIMPULAN}

Berdasarkan paparan dan analisis data dapat disimpulkan bahwa penerapan PBL pada penelitian ini telah meningkatkan kemampuan representasi matematis siswa. Peningkatan ini dapat dilihat dari hasil capaian kemampuan representasi matematis pada tes akhir siklus dan hasil observasi aktivitas guru dan siswa dari siklus I ke siklus II. Pembelajaran telah mampu membuat siswa lebih mandiri dalam mengembangkan pengetahuan mereka. Pembelajaran telah berpusat pada siswa. Siswa lebih berani dalam menyampaikan ide-idenya, dan lebih aktif dalam pembelajaran dibandingkan dengan sebelum diberi tindakan.

Berdasarkan hasil penelitian, ada beberapa saran untuk peneliti selanjutnya dan guru. Pertama, penyajian masalah pada PBL dapat dikembangkan lebih luas pada berbagai bidang kehidupan. Kedua, masalah yang dikaji tidak terbatas pada masalah program linear dua variabel, namun dapat dikembangkan pada materi matematika yang lain. Ketiga, alokasi waktu pada tahap pembelajaran diatur secara cermat agar pembelajaran berlangsung secara efektif. Keempat, model pembelajaran PBL dapat dijadikan alternatif model pembelajaran pada materi program linear.

\section{DAFTAR RUJUKAN}

Arends, R. I. (2012). Learning to Teach Ninth Edition. New York: Mc Graw Hill Book Co.

Arnidha, Y. (2016). Peningkatan Kemampuan Representasi Matematis Siswa melalui Pembelajaran Kooperatif Think Pair Share. Jurnal E-DuMath, 2(1), 128-137.

Chakrabarty, S., \& Mohamed, N. (2013). Problem Based Learning: Cultural Diverse Students 'Engagement, Learning and Contextualized Problem Solving in a Mathematics Class. WCIK E-Journal of Inegration Knowledge, 38-49. 
Dahlan, J. A., \& Juandi, D. (2011). Analisis Representasi Matematik Siswa Sekolah Dasar Dalam Penyelesaian Masalah Matematika Kontekstual. Jurnal Pengajaran Matematika dan Ilmu Pengetahuan Alam, 16(1), 128.

Debrenti, E. (2015). Visual Representations in Mathematics Teaching: An Experiment with Students. Acta Didactica Napocensia, 8(1), 1-15.

Farhan, M., \& Retnawati, H. (2014). Keefektifan PBL dan IBL Ditinjau dari Prestasi Belajar Kemampuan Representasi Matematis dan Motivasi Belajar. Jurnal Riset Pendidikan Matematika, 1(2), 227-240.

Faruq, A., Yuwono, I., \& Chandra, T. D. (2016). Representasi (eksternal-internal) pada Penyelesaian Masalah Matematika. Jurnal Review Pembelajaran Matematika, 1(2), 149-162.

Fitri, N., Munzir, S., \& Duskri, M. (2017). Meningkatkan Kemampuan Representasi Matematis melalui Penerapan Model Problem Based Learning. Jurnal Didaktik Matematika, 4(1), 59-67.

Hakim, L. (2012). Perencanaan Pembelajaran. Bandung: CV. Wacana Prima.

Hutagaol, K. (2013). Pembelajaran Kontekstual untuk Meningkatkan Kemampuan Representasi Matematis Siswa Sekolah Menengah Pertama. Jurnal Ilmiah Program Studi Matematika STKIP Siliwangi Bandung, 2(1), 85-99.

Hwang, W. Y., Chen, N. S., Dung, J. J., \& Yang, Y. L. (2007). Multiple Representation Skills and Creativity Effects on Mathematical Problem Solving Using A Multimedia Whiteboard System. Journal of Educational Technology \& Society, 10(2), 191-212.

José Madrid, M., Maz-Machado, A., \& León-Mantero, C. (2015). Representations in the Sixteenth-Century Arithmetic Books. Universal Journal of Educational Research, 3(6), 396-401.

Kartini. (2009). Peranan Representasi dalam Pembelajaran Matematika. Seminar Nasional Matematika dan Pendidikan Matematika UNY, 978-979.

Kusumaningsih, W., \& Marta, R. P. (2016). Pengaruh Pembelajaran Berbasis Masalah dan Discovery Learning terhadap Kemampuan Representasi Matematis Siswa SMP. Jurnal Ilmiah Pendidikan Matematika, 1(2), 135-144.

Macmath, Sheryl, Wallace, J., \& Xiaohong, C. (2009). Problem-Based Learning in Mathematics (A Tool for Developing Students' Conceptual Knowledge). University of Toronto: A Partnership between the Literacy Secretariat and the Ontario Association of Deans of Education.

Minarni, A., Napitupulu, E. E., \& Husein, R. (2016). Mathematical Understanding and Representation Ability of Public Junior High School in North Sumatra. Journal on Mathematics Education, 7(1), 45-58.

NCTM. (2000). Principles and Standards for School Mathematics. Reston: The National Council of Teachers of Mathematics, Inc.

Priyono, S., Hermanto, R., Studi, P., Matematika, P., \& Siliwangi, U. (2015). Peningkatan Kemampuan Representasi Matematik Peserta Didik dengan Menggunakan Model Problem Based Learning (PBL) Berbantuan Media Software Geogebra. Jurnal Penelitian Pendidikan dan Pengajaran Matematika, 1(1), 55-64.

Rahmad, B. A., Ipung, Y., Abdur, R. A., Sisworo, \& Dwi, R. (2016). Mathematical Representation by Students in Building Relational Understanding on Concepts of Area and Perimeter of Rectangle. Educational Research and Reviews, 11(21), 2002-2008.

Rashid, R. A. B. (2011). Research Papers A Perspective Evaluation of Problem-Based Learning In ESL Classroom in The Malaysian Higher School Certificate Program. Journal on English Language Teaching, 1(4), $25-32$.

Sabirin, M. (2014). Representasi Dalam Pembelajaran Matematika. JPM IAIN Antasari, 01(2), 33-44.

Savery, J. (2006). Overview of Problem-Based Learning : Defenitions and Distinction. The Interdisciplinary Journal of Problem-Based Learning, I, 3-14.

Thompson, D. R., \& Chappell, M. F. (2007). Communication and Representation as Elements in Mathematical Literacy. Reading and Writing Quarterly, 23(2), 179-196. 